\title{
Carotenoids are related to the colour and lipid content of the pequi (Caryocar brasiliense Camb.) pulp from the Brazilian Savanna
} Débora Melo RIBEIRO ${ }^{1}$, Daniela Canuto FERNANDES ${ }^{1}$, Aline Medeiros ALVES², Maria Margareth Veloso NAVES ${ }^{2 *}$

\begin{abstract}
This study investigated the colour, proximate composition, bioactive compounds (phenolic and carotenoid contents), and antioxidant activity of the pulp of pequi from different regions of the Brazilian Savanna. The colour parameters and the lipid and carotenoid contents of the pulp were significantly different between the samples. The lipid content ranged from 135.4 to $322.5 \mathrm{~g} / \mathrm{kg}$. The pequi pulp showed high total phenolic content (1.8 to $3.3 \mathrm{mg} \mathrm{GAE} / \mathrm{g}$ ). The carotenoid amount ranged from 37 to $187 \mu \mathrm{g} / \mathrm{g}$. The carotenoid content was significantly correlated with the colour and lipid content of the pequi pulp. The antioxidant activity showed a mean $\mathrm{IC}_{50}$ value of $197.9 \mu \mathrm{g} / \mathrm{mL}$. The pequi pulp is rich in phenolic compounds and carotenoids and has a good antioxidant activity. Its colour is influenced by the carotenoid content, which can be predicted by regression models using routine colour parameters.
\end{abstract}

Keywords: Caryocar brasiliense Camb.; native fruits; Savanna; bioactive compounds; antioxidant capacity.

\section{Introduction}

The Brazilian Savanna (Cerrado) is the second largest biome in Brazil and is located mainly in the mid-western region of the country. The Brazilian Savanna has several fruit-bearing species with a great potential for agricultural and technological uses (Carvalho et al., 2009; Castro et al., 1999). Among these native fruits, pequi (Caryocar brasiliense Camb.) is the most expressive example; its pulp has an intense colour that ranges from light yellow to dark orange and a striking and peculiar flavour (Geöcze et al., 2013).

Pequi pulp is often consumed and appreciated by the population of the Brazilian Savanna, either in its homemade or industrial form, and its harvest period varies from September to February (Araújo, 1995). In addition to its gastronomic and technological potentials, studie suggests that pequi has a good antioxidant potential (Morais et al., 2013). However, research regarding the carotenoid and phenolic contents of its pulp is limited in number and sample stratification since sampling has been restricted to a small area of the Cerrado or even reduced to a single plant (Azevedo-Meleiro \& Rodriguez-Amaya, 2004; Rodriguez-Amaya et al., 2008).

The lack of sample stratification is an important limitation in food research, mainly for native fruits, since studies on the biodiversity of the Brazilian Savanna have shown that there is a great variability of physical (Moura et al., 2013; Vera et al., 2005) and chemical (Czeder et al., 2012) properties of the native fruits from different area of the biome. Therefore, this study tested the hypothesis that there are differences in colour, chemical properties and antioxidant activity of pequi fruits from different regions of the Brazilian Savanna, and that these properties are interrelated. Thus, the present study analysed and compared the colour and chemical and antioxidant properties of pequi fruit samples from five different regions of the Brazilian Savanna, and the correlations among the variables were tested.

\section{Materials and methods}

\subsection{Fruit sampling}

Five fruit samples were obtained from native pequi plants from different regions of the Brazilian Savanna: North (latitude: $08^{\circ} 32^{\prime} 20^{\prime \prime}$, longitude: $\left.48^{\circ} 30^{\prime} 21^{\prime \prime}\right)$, South (latitude: $16^{\circ} 51^{\prime} 39^{\prime \prime}$, longitude: $\left.44^{\circ} 54^{\prime} 50^{\prime \prime}\right)$, West (latitude: $15^{\circ} 51^{\prime} 57^{\prime \prime}$, longitude: $\left.56^{\circ} 04^{\prime} 37^{\prime \prime}\right)$, East (latitude: $15^{\circ} 59^{\prime} 42^{\prime \prime}$, longitude: $44^{\circ} 16^{\prime} 12^{\prime \prime}$ ), and Central (latitude: $16^{\circ} 37^{\prime} 08^{\prime \prime}$, longitude: $48^{\circ}$ $\left.44^{\prime} 38^{\prime \prime}\right)$. These areas are representative of the production of the native pequi from the Cerrado biome. The samples were obtained in different months, according to the harvest period in each region: North - October 2010; Central - December 2010; South - December 2010; East - January 2011; West - January 2011. The fruits acquired were newly collected and at optimum maturity for commercial use.

\subsection{Pequi pulp colour analysis}

The colour analysis was performed with 30 pequi fruits from each savanna region, randomly selected from a total of $50 \mathrm{~kg}$. This analysis, which was performed in peeled fruits using a Sphere Colorimeter - Color Quest II (Hunter Lab, Reston, VA, USA) to determine the following CIE (Commission Internationale de l'éclairage) parameters: $\mathrm{L}^{*}$ (whiteness or brightness), $\mathrm{a}^{*}$ (redness/greenness), and $\mathrm{b}^{\star}$ (yellowness/ blueness) (Lancaster et al., 1997). Colour intensity (chroma) 
(Equation 1) and hue angle (Equation 2) were calculated using the following equations (McGuire, 1992):

Chroma $(\mathrm{C})=\left(\mathrm{a}^{* 2}+\mathrm{b}^{* 2}\right)^{1 / 2}$

Hue angle $(\mathrm{h})=\tan ^{-1}\left(\mathrm{~b} * / \mathrm{a}^{*}\right)$

\subsection{Chemical analyses of the pequi pulp}

\section{Sample preparation}

For the chemical analyses, the pequi fruits were peeled and pulped manually using a stainless steel knife. Then, the fruit pulp was ground and homogenized in a food processor HL-3253 (Walita, São Paulo, Brazil), packaged in opaque bags, and stored at $-45^{\circ} \mathrm{C}$ until analyses. For the analyses of the total phenolic and carotenoid content, whole fruits were frozen and stored at $-45^{\circ} \mathrm{C}$ until analysis.

\section{Proximate composition}

The following analyses were performed: moisture (Association of Official Analytical Chemists, 2002); total nitrogen, according to the micro-Kjeldahl method and converted into protein using the factor 6.25 (Association of Official Analytical Chemists, 2002); total lipids, extracted using the technique of Bligh and Dyer (1959) and subsequently measured by gravimetry; ash, by burning in an oven at $550^{\circ} \mathrm{C}$; and total dietary fibre (Association of Official Analytical Chemists, 2002). The total carbohydrates were estimated by difference, subtracting the values obtained for moisture, protein, fat, ash and fibre from one hundred. The energy value of the samples was estimated based on the proximate composition data, considering the Atwater conversion factors, which are 4, 4 , and $9 \mathrm{kcal} / \mathrm{g}$ for protein, carbohydrate, and lipid, respectively (Merril \& Watt, 1973). The analyses were performed in triplicate.

\section{Fatty acid composition}

To determine the fatty acid composition, the samples were extracted as described by Folch et al. (1957) and esterified according to Hartman \& Lago (1973). Fatty acids were separated by Finnigan Focus GC gas chromatography (Thermo, Austin, TX, USA) with a flame ionization detector and capillary column (RESTEK, Bellefonte, PA, USA - polyethylene glycol crossbond - $30 \mathrm{~m} \times 0.25 \mathrm{~mm}$ ) of fused silica. The running conditions were: carrier gas - hydrogen $(2 \mathrm{~mL} / \mathrm{min})$; make up gas - nitrogen $(28 \mathrm{~mL} / \mathrm{min})$; and hydrogen $(30 \mathrm{~mL} / \mathrm{min})$, and synthetic air $(300 \mathrm{~mL} / \mathrm{min})$ in order to maintain the detector flame. The injection volume was $1 \mu \mathrm{L}$ and split ratio of 2:98. Retention time, peak area, and area relative percentage values were obtained using the Chrom Quest 4.1 software. Fatty acids were identified and quantified by reference to the calibration curve prepared with standard methyl esters of fatty acids (Sigma Aldrich). The analyses were performed in triplicate.

\section{Total phenolic content}

The total phenolic content was determined by the method described by Swain \& Hillis (1959) using the Folin-Ciocalteu's reagent. The extract was obtained as follows: first extraction with
9.52 $\mathrm{M}$ acetone, followed by a second extraction with $12.33 \mathrm{M}$ methanol. Then, the extract $(0.6 \mathrm{~mL})$ was added to $5.0 \mathrm{~mL}$ of distilled water, and $1.0 \mathrm{~mL}$ of the Folin-Ciocalteu's phenol reagent and $1.0 \mathrm{~mL}$ of $0.24 \mathrm{M}$ sodium carbonate were added to the mixture. The mixture was agitated and incubated at $25^{\circ} \mathrm{C}$ for $30 \mathrm{~min}$. The absorbance at $700 \mathrm{~nm}$ was measured using a spectrophotometer V-630 (JASCO, Tokyo, Japan). A standard curve of gallic acid was drawn, and absorbance was converted to phenolic content in terms of $\mathrm{mg}$ of gallic acid equivalents (GAE) per g of pulp. The analyses were performed in triplicate.

\section{Total carotenoid content}

The total carotenoid content of the pequi pulp was analysed according to the method described by Higby (1962). The extractions were performed using $25 \mathrm{~mL}$ of cold acetone and $1.0 \mathrm{~g}$ of pulp mixed with $0.1 \%$ of butyl hydroxy toluene (BHT). The residue was re-extracted until it became colourless. The extracts were transferred to petroleum ether, and the filtrates were combined in a separatory funnel and washed with distilled water. The water phase was discarded, and sodium sulphate was added as a desiccant. The ether phase was transferred to a $100 \mathrm{~mL}$ volumetric flask and brought to volume with petroleum ether. The absorbance of the extracts was measured from 250 to $700 \mathrm{~nm}$ in a spectrophotometer. To determine the total carotenoid content, the highest value of absorbance detected was considered. The total carotenoid content was calculated using the absorbance of anteraxantin at $1 \mathrm{~g} / \mathrm{mL}$, which has an extinction coefficient of 2350 (Chisté \& Mercadante, 2012). The analyses were performed in triplicate.

\subsection{Evaluation of antioxidant activity of the pequi pulp}

The antioxidant activity of the pequi pulp was measured using a 2,2-diphenyl-1-picrylhydrazyl (DPPH•)-free radical scavenging assay, according to the method of BrandWilliams et al. (1995) with some adaptations. The extraction experiments were conducted using $50 \mathrm{~mL}$ of ethanol and $2.5 \mathrm{~g}$ of pulp. Then, $1.5 \mathrm{~mL}$ of a $0.05 \mathrm{mM}$ DPPH• solution was added to the extracts. The decrease in the absorbance at $517 \mathrm{~nm}$ at 0 , $1,2,3,4,5,10,15$, and $20 \mathrm{~min}$ of the reaction was measured using a spectrophotometer V-630 (JASCO, Tokyo, Japan). The decrease in the sample absorbance readings was related to the control (without the extract), and the percentage of $\mathrm{DPPH} \bullet$ discoloration was estimated. Based on this value, the $\mathrm{IC}_{50}$ (concentration of the sample required to inhibit $50 \%$ of the radical) was calculated. BHT was used as a standard. The analyses were performed in triplicate.

\subsection{Statistical analysis}

The values of colour, proximal composition, total phenolic, carotenoid content, and antioxidant activity obtained were submitted to variance analysis, and the comparisons between the means were performed by the Tukey test. The coefficient of correlation $r$ was calculated to assess the correlations between the variables. Statistical calculations were performed using the Statistica software (Stat Soft Inc., 7.0 version, 2004, Tulsa, USA). A significance level of $5 \%$ was adopted. 


\section{Results and discussion}

\subsection{Pequi pulp colour}

The fruits from the North and Central regions showed higher values of $\mathrm{L}^{*}($ mean $=70.8)$ and lower values of $\mathrm{a}^{*}$ (mean $=23.7$ ), which indicate lighter coloured and less red fruits. In contrast, the fruits from the East region were darker and redder (Table 1). There was a positive correlation between $\mathrm{L}^{*}$ and the parameter $\mathrm{a}^{\star}(p=0.001)$. The pequis from the North region showed the highest $b^{*}$ values. The lowest values were observed in fruits from the East and Central regions (Table 1). The variation in this parameter is due to the great amplitude of the yellow colour of the pequi pulp. The parameter $\mathrm{C}$ ranged from 75 to 115 and was positively correlated with the parameter $\mathrm{b}^{*}(p=0.006)$. The hue angles of the pequi pulps ranged from approximately $55^{\circ}$ to $80^{\circ}$, indicating a fruit colour from orange-red to intense yellow since lower hue angle values corresponded to more orange-red pulps and higher hue angles corresponded to more yellow pulps. There are no studies on the CIE parameters of pequi pulps in the literature.

\subsection{Chemical characteristics of pequi pulp}

The pequi pulp showed moisture content greater than $500 \mathrm{~g} / \mathrm{kg}$ and protein content less than $30 \mathrm{~g} / \mathrm{kg}$ (Table 2), similar values to those reported for other pulps of exotic fruits (Clerici \& Carvalho-Silva, 2011). There was a significant variation in the lipid content of the pequi pulps (approximately 147 to $322 \mathrm{~g} / \mathrm{kg}$ ); however, a narrower range of lipid content for the C. brasiliense - 200 to $330 \mathrm{~g} / \mathrm{kg}$ - has been reported in the literature (Lima et al., 2007; Vera et al., 2007). The wide variation observed in the lipid content of the pequi pulps is most likely due to different genetic profiles in the same pequi species. The monounsaturated fats were the most prevalent among the fatty acids in all samples, mainly oleic acid (Table 3 ). The energy values found in this study varied according to the lipid content of the fruits. The fruits from the West region showed the highest energy values (greater than $3000 \mathrm{kcal} / \mathrm{kg}$ ), which is compatible with the literature (Lima et al., 2007). On the other hand, lower energy values of approximately $1500 \mathrm{kcal} / \mathrm{kg}$ (Table 2) were found for the pequi fruit, which represent lighter pulps than that of the cited study $(3584 \mathrm{kcal} / \mathrm{kg})$. The pequi pulps also had high percentage of total dietary fibre, mainly insoluble fibre (Table 2). A portion of $20 \mathrm{~g}$ of pequi pulp provides around $10 \%$ of the Dietary Reference Intake (DRI) for dietary fibre (Institute of Medicine, 2005). The pequi pulp contains low levels of carbohydrates, ranging from 6.0 (Central region) to $70.2 \mathrm{~g} /$ $\mathrm{kg}$ (East region) (Table 2).

The fruits from the Central region had the highest value of total phenolic content (Table 4), which is higher than the previously reported value (2.09 $\mathrm{mg} \mathrm{GAE} / \mathrm{g}$ ) (Lima et al., 2007). The phenolic content found in the pequi pulp in this study is comparable with that of the other exotic fruits, such as blackberry, cactus pear, and mangaba (Clerici \& CarvalhoSilva, 2011).

Regarding the total carotenoid content, values ranging from 37 (North region) to $187 \mu \mathrm{g} / \mathrm{g}$ (East region) were found (Table 4). The only previous study on the total carotenoid content in pequi fruits of the same species investigated in the present study reported an intermediate value, $72.5 \mu \mathrm{g} / \mathrm{g}$ (Lima et al., 2007). The identification and quantification of the carotenoids of the C. brasiliense are an important tool to clarify the differences

Table 1. Colour parameters of pequi pulp from five regions of the Brazilian Savanna ${ }^{1}$.

\begin{tabular}{cccccc}
\hline Region & $\mathrm{L}^{\star}$ & $\mathrm{a}^{\star}$ & $\mathrm{b}^{\star}$ & $\mathrm{C}$ & $\mathrm{h}^{\star}\left({ }^{\circ}\right)$ \\
\hline North & $72.86 \pm 2.54^{\mathrm{a}}$ & $23.34 \pm 6.52^{\mathrm{c}}$ & $112.94 \pm 17.15^{\mathrm{a}}$ & $115.42 \pm 17.39^{\mathrm{a}}$ & $78.38 \pm 2.40^{\mathrm{a}}$ \\
South & $59.99 \pm 12.07^{\mathrm{c}}$ & $35.11 \pm 11.39^{\mathrm{b}}$ & $97.08 \pm 19.84^{\mathrm{b}}$ & $107.11 \pm 8.15^{\mathrm{a}}$ & $69.04 \pm 5.30^{\mathrm{b}}$ \\
East & $43.63 \pm 7.40^{\mathrm{e}}$ & $54.10 \pm 3.97^{\mathrm{a}}$ & $75.20 \pm 12.74^{\mathrm{c}, \mathrm{d}}$ & $93.13 \pm 9.12^{\mathrm{b}}$ & $53.74 \pm 5.98^{\mathrm{d}}$ \\
West & $48.11 \pm 4.72^{\mathrm{d}}$ & $42.19 \pm 4.02^{\mathrm{b}}$ & $82.73 \pm 8.01^{\mathrm{c}}$ & $93.13 \pm 5.52^{\mathrm{b}}$ & $63.08 \pm 4.53^{\mathrm{c}}$ \\
Central & $68.77 \pm 5.61^{\mathrm{b}}$ & $24.10 \pm 11.97^{\mathrm{c}}$ & $70.81 \pm 21.13^{\mathrm{d}}$ & $75.22 \pm 22.90^{\mathrm{c}}$ & $72.16 \pm 7.04^{\mathrm{b}}$ \\
\hline
\end{tabular}

${ }^{1}$ The values are expressed as means \pm standard deviation of the triplicate analysis of each region. Means in the same column with the same letter are not significantly different according to the Tukey test ( $5 \%$ of probability).

Table 2. Proximate composition $(\mathrm{g} / \mathrm{kg})$ of pequi pulp from five regions of the Brazilian Savanna ${ }^{1}$.

\begin{tabular}{|c|c|c|c|c|c|}
\hline \multirow{2}{*}{ Proximate composition } & \multicolumn{5}{|c|}{ Region } \\
\hline & North & South & East & West & Central \\
\hline Moisture & $702.0 \pm 6.8^{\mathrm{b}}$ & $686.7 \pm 10.5^{\mathrm{b}}$ & $523.7 \pm 13.4^{\mathrm{c}}$ & $531.4 \pm 1.1^{\mathrm{c}}$ & $740.9 \pm 8.1^{\mathrm{a}}$ \\
\hline Proteins & $16.0 \pm 2.5^{\mathrm{c}}$ & $19.4 \pm 2.2^{\mathrm{b}, \mathrm{c}}$ & $29.0 \pm 4.9^{\mathrm{a}}$ & $26.3 \pm 2.8^{\mathrm{a}, \mathrm{b}}$ & $13.0 \pm 0.1^{\mathrm{c}}$ \\
\hline Lipids & $147.7 \pm 7.6^{c}$ & $135.4 \pm 13.9^{c}$ & $271.3 \pm 8.9^{\mathrm{b}}$ & $322.5 \pm 18.7^{\mathrm{a}}$ & $152.1 \pm 9.1^{\mathrm{c}}$ \\
\hline Dietary fibre total & $93.5 \pm 0.3^{c}$ & $113.9 \pm 1.4^{\mathrm{a}}$ & $99.1 \pm 1.7^{\mathrm{b}}$ & $81.7 \pm 0.2^{\mathrm{d}}$ & $81.2 \pm 1.9^{\mathrm{d}}$ \\
\hline insoluble & $70.3 \pm 0.2^{\mathrm{b}}$ & $82.8 \pm 2.0^{\mathrm{a}}$ & $74.3 \pm 3.2^{\mathrm{b}}$ & $59.4 \pm 0.0^{c}$ & $59.1 \pm 0.1^{\mathrm{c}}$ \\
\hline soluble & $23.2 \pm 0.4^{\mathrm{b}, \mathrm{c}}$ & $31.1 \pm 0.7^{\mathrm{a}}$ & $24.8 \pm 1.7^{\mathrm{b}}$ & $22.3 \pm 0.2^{c}$ & $22.0 \pm 0.6^{c}$ \\
\hline Ash & $9.2 \pm 0.2^{\mathrm{a}}$ & $7.0 \pm 0.3^{b}$ & $6.7 \pm 0.5^{\mathrm{b}}$ & $9.3 \pm 0.2^{\mathrm{a}}$ & $6.8 \pm 0.2^{\mathrm{b}}$ \\
\hline Carbohydrates & $31.6 \pm 10.3^{\mathrm{b}}$ & $37.6 \pm 12.7^{\mathrm{a}, \mathrm{b}}$ & $70.2 \pm 17.9^{\mathrm{a}}$ & $28.8 \pm 7.4^{\mathrm{b}}$ & $6.0 \pm 4.8^{\mathrm{b}}$ \\
\hline Total energy value $(\mathrm{kcal} / \mathrm{kg})$ & $1519.6 \pm 55.1^{\mathrm{c}}$ & $1446.5 \pm 96.7^{c}$ & $2839.1 \pm 67.5^{\mathrm{b}}$ & $3084.0 \pm 103.7^{\mathrm{a}}$ & $1433.6 \pm 82.2^{c}$ \\
\hline
\end{tabular}

${ }^{1}$ The values are expressed as means \pm standard deviation of the triplicate analysis of each region. Means in the same row with the same letter are not significantly different according to the Tukey test ( $5 \%$ of probability). 
found in the present study, as recently reported for the Caryocar villosum (Chisté \& Mercadante, 2012; Chisté et al., 2012). There was a linear and positive correlation between the carotenoid and lipid contents of the pequi pulp ( $r=0.67, p=0.002)$, confirming the lipophilic nature of carotenoids (Amorim-Carrilho et al., 2014).

It is important to note that the great variation of the physical and chemical characteristics of the pequi fruits from the different regions studied may occur due to differences in the climate, soil fertility and $\mathrm{pH}$, annual rainfall, and other environmental conditions observed in the Brazilian Savanna biome (Novaes et al., 2013).

\subsection{Antioxidant activity}

All extracts showed the ability to sequester the free radical DPPH (Table 4). The fruits from the East and West regions showed higher antioxidant activity than the fruits from the other regions. These values are comparable with those of other exotic fruits (Dembitsky et al., 2011). A lower antioxidant activity $\left(\mathrm{IC}_{50}=298 \mu \mathrm{g} / \mathrm{mL}\right.$ ) than those found in the present study (Table 4) was reported for the pulp + seed of the pequi fruit (Roesler et al., 2007).

\subsection{Relationship between colour parameters and carotenoid content}

According to the $r$ coefficient values (Table 5), there are strong significantly $(p<0.001)$ correlations between luminosity and the carotenoid content and between the hue angle and carotenoid content in the pequi pulp. In addition, a significant correlation between the carotenoid content and the parameters $\mathrm{a}^{*}$ and $\mathrm{b}^{\star}$ was observed. These correlations are a useful tool for the technological and commercial uses of the pequi pulp because the equations presented in Table 5 can predict the carotenoid content using routine colour parameters.

Table 3. Fatty acid composition (g/kg of lipid) of pequi pulp from five regions of the Brazilian Savanna ${ }^{1}$.

\begin{tabular}{|c|c|c|c|c|c|}
\hline \multirow{2}{*}{$\begin{array}{c}\text { Fatty acid } \\
\text { (main components) }\end{array}$} & \multicolumn{5}{|c|}{ Region } \\
\hline & North & South & East & West & Central \\
\hline Saturated & $299.7 \pm 2.5^{\mathrm{d}}$ & $394.2 \pm 5.2^{\mathrm{b}}$ & $368.8 \pm 4.7^{c}$ & $431.9 \pm 2.0^{\mathrm{a}}$ & $384.1 \pm 0.1^{\mathrm{b}}$ \\
\hline Myristic C14:0 & $1.0 \pm 0.0^{\mathrm{b}}$ & $1.0 \pm 0.0^{\mathrm{a}, \mathrm{b}}$ & $1.1 \pm 0.1^{\mathrm{a}}$ & $0.6 \pm 0.0^{c}$ & $1.1 \pm 0.1^{\mathrm{a}, \mathrm{b}}$ \\
\hline Palmitic C16:0 & $281.4 \pm 2.8^{\mathrm{d}}$ & $367.8 \pm 5.6^{\mathrm{b}}$ & $343.9 \pm 4.6^{c}$ & $405.0 \pm 1.8^{\mathrm{a}}$ & $359.6 \pm 0.2^{\mathrm{b}}$ \\
\hline Stearic C18:0 & $13.9 \pm 0.1^{\mathrm{d}}$ & $20.7 \pm 0.7^{b}$ & $18.5 \pm 0.1^{\mathrm{c}}$ & $22.8 \pm 0.1^{\mathrm{a}}$ & $20.1 \pm 0.0^{\mathrm{b}}$ \\
\hline Monounsaturated & $643.6 \pm 3.6^{\mathrm{a}}$ & $525.2 \pm 14.5^{c}$ & $559.7 \pm 1.6^{\mathrm{b}}$ & $510.0 \pm 0.0^{c}$ & $537.0 \pm 0.2^{\mathrm{b}, \mathrm{c}}$ \\
\hline Palmitoleic C16:1 n7 & $3.9 \pm 0.0^{\mathrm{e}}$ & $11.8 \pm 0.1^{\mathrm{a}}$ & $6.7 \pm 0.2^{\mathrm{d}}$ & $10.2 \pm 0.0^{\mathrm{b}}$ & $9.5 \pm 0.0^{c}$ \\
\hline Oleic C18:1 cis n9 & $635.4 \pm 3.5^{\mathrm{a}}$ & $507.2 \pm 15.0^{\mathrm{c}, \mathrm{d}}$ & $547.6 \pm 1.3^{\mathrm{b}}$ & $498.3 \pm 0.1^{\mathrm{d}}$ & $526.0 \pm 0.2^{\mathrm{b}, \mathrm{c}}$ \\
\hline Polyunsaturated & $16.1 \pm 0.0^{\mathrm{a}}$ & $15.6 \pm 0.7^{b}$ & $16.9 \pm 0.0^{a}$ & $11.5 \pm 0.0^{c}$ & $15.8 \pm 0.0^{\mathrm{b}}$ \\
\hline Linoleic C18:2 n6 & $16.1 \pm 0.0^{\mathrm{a}}$ & $11.3 \pm 0.3^{c}$ & $12.8 \pm 0.0^{\mathrm{b}}$ & $11.3 \pm 0.0^{c}$ & $15.8 \pm 0.0^{\mathrm{a}}$ \\
\hline Eicosapentaenoic C20:5 n3 & ND & $2.7 \pm 0.3$ & $2.4 \pm 0.1$ & ND & ND \\
\hline
\end{tabular}

$\mathrm{ND}$ - not detected. ${ }^{1}$ The values are expressed as means \pm standard deviation of the triplicate analysis of each region. Means in the same row with the same letter are not significantly different according to the Tukey test ( $5 \%$ of probability).

Table 4. Total phenolic and total carotenoid content and antioxidant activity (alcoholic extract) of pequi pulp from five regions of the Brazilian Savanna ${ }^{1}$.

\begin{tabular}{cccc}
\hline Region & Total phenolics $(\mathrm{mg} \mathrm{GAE} / \mathrm{g})$ & Total carotenoid $(\mu \mathrm{g} / \mathrm{g})$ & ${\text { Antioxidant activity }\left(\mathrm{IC} \mathrm{C}_{50^{\prime}} \mu \mathrm{g} / \mathrm{mL}\right)}^{\mathrm{c}}$ \\
\hline North & $1.78 \pm 0.01^{\mathrm{c}}$ & $37.08 \pm 1.84^{\mathrm{d}}$ & $197.93 \pm 2.17^{\mathrm{a}}$ \\
South & $2.23 \pm 0.14^{\mathrm{b}}$ & $141.89 \pm 6.76^{\mathrm{b}}$ & $202.00 \pm 5.15^{\mathrm{a}}$ \\
East & $2.16 \pm 0.17^{\mathrm{b}, \mathrm{c}}$ & $187.00 \pm 12.43^{\mathrm{a}}$ & $194.30 \pm 2.68^{\mathrm{b}}$ \\
West & $1.80 \pm 0.04^{\mathrm{c}}$ & $155.23 \pm 0.53^{\mathrm{b}}$ & $195.97 \pm 5.16^{\mathrm{b}}$ \\
Central & $3.34 \pm 0.07^{\mathrm{a}}$ & $72.10 \pm 3.58^{\mathrm{c}}$ & $199.40 \pm 3.14^{\mathrm{a}}$ \\
\hline
\end{tabular}

GAE: Gallic Acid Equivalents. ${ }^{1}$ The values are expressed as means \pm standard deviation of the triplicate analysis of each region. Means in the same column with the same letter are not significantly different according to the Tukey test ( $5 \%$ of probability).

Table 5. Relationship between colour parameters and total carotenoid content of pequi pulp from the Brazilian Savanna.

\begin{tabular}{ccrr}
\hline Colour parameter & Regression model & Correlation coefficient $r$ & $p$ value \\
\hline $\mathrm{L}^{*}$ & $\mathrm{Y}=378.4216-4.4004 . \mathrm{L}$ & -0.91 & $<0.0001$ \\
$\mathrm{a}^{*}$ & $\mathrm{Y}=-27.4857+3.6537 . \mathrm{a}^{*}$ & 0.81 & $<0.0001$ \\
$\mathrm{~b}^{*}$ & $\mathrm{Y}=266.8659-1.7275 . \mathrm{b}^{*}$ & -0.69 & 0.0030 \\
$\mathrm{~h}$ & $\mathrm{Y}=509.3911-5.8076 . \mathrm{h}$ & -0.89 & $<0.0001$ \\
\hline
\end{tabular}




\section{Conclusions}

Colour and the lipid and carotenoid contents are influenced by the native region of the pequi fruit. The carotenoid content is positively related to the colour and the lipid content of the pequi pulp. The pequi pulp is rich in phenolic compounds and carotenoids, and it has good antioxidant activity. The regression models developed enable the prediction of the total carotenoid content of the pequi pulp using routine colour parameters.

\section{Acknowledgements}

The authors are grateful to CNPq and CAPES (Brazil) for the financial support, to professor Dr. Ronaldo Veloso Naves, School of Agronomy (UFG), for his guidance in collecting the pequi fruit, and to Dr. Tânia S. Agostini-Costa, Embrapa Cenargen, Brasília-DF, Brazil, for her assistance in the carotenoid analysis.

\section{References}

Amorim-Carrilho, K. T., Cepeda, A., Fente, C., \& Regal, P. (2014). Review of methods for analysis of carotenoids. Trends in Analytical Chemistry, 56(1), 49-73. http://dx.doi.org/10.1016/j. trac.2013.12.011

Association of Official Analytical Chemists - AOAC. (2002). Official Methods of Analysis of the AOAC International. Gaithersburg.

Araújo, F. D. (1995). A review of Caryocar brasiliense (Caryocaraceae): an economically valuable species of the central Brazilian cerrados. Economic Botany, 49(1), 40-48. http://dx.doi.org/10.1007/ BF02862276

Azevedo-Meleiro, C. H., \& Rodriguez-Amaya, D. B. (2004). Confirmation of the identity of the carotenoids of tropical fruits by HPLC-DAD and HPLC-MS. Journal of Food Composition and Analysis, 17(3), 385-396. http://dx.doi.org/10.1016/j. jfca.2004.02.004

Bligh, E. G., \& Dyer, W. J. (1959). A rapid method of total lipid extraction and purification. Canadian Journal of Biochemistry and Physiology, 37(8), 911-917. PMid:13671378. http://dx.doi. org/10.1139/o59-099

Brand-Williams, W., Cuvelier, M. E., \& Berset, C. (1995). Use of a free radical method to evaluate antioxidant activity. $L W T$ - Food Science and Technology, 28(1), 25-30. http://dx.doi.org/10.1016/ S0023-6438(95)80008-5

Carvalho, F. M. V., Marco Júnior, P., \& Ferreira, L. G. (2009). The Cerrado intopieces: habitat fragmentation as a function of landscape use in the savannas of central Brazil. Biological Conservation, 142(7), 1392-1403. http://dx.doi.org/10.1016/j.biocon.2009.01.031

Castro, A. A. J. F., Martins, F. R., Tamashiro, J. Y., \& Sheperd, G. J. (1999). How rich is the flora of Brazilian Cerrados? Annals of the Missouri Botanical Garden, 86(1), 192-224. http://dx.doi. org/10.2307/2666220

Chisté, R. C., Freitas, M., Mercadante, A. Z., \& Fernandes, E. (2012). The potential of extracts of Caryocar villosum pulp to scavenge reactive oxygen and nitrogen species. Food Chemistry, 135(3), 1740-1749. PMid:22953916. http://dx.doi.org/10.1016/j.foodchem.2012.06.027

Chisté, R. C., \& Mercadante, A. Z. (2012). Identification and quantification, by HPLC-DAD-MS/MS, of carotenoids and phenolic compounds from the Amazonian fruit Caryocar villosum. Journal of Agricultural and Food Chemistry, 60(23), 5884-5892. PMid:22612541. http://dx.doi.org/10.1021/jf301904f
Clerici, M. T. P. S., \& Carvalho-Silva, L. B. (2011). Nutritional bioactive compounds and technological aspects of minor fruits grown in Brazil. Food Research International, 44(7), 1658-1670. http://dx.doi. org/10.1016/j.foodres.2011.04.020

Czeder, L. P., Fernandes, D. C., Freitas, J. B., \& Naves, M. M. V. (2012). Baru almonds from different regions of the Brazilian Savanna: implications on physical and nutritional characteristics. Agricultural Science, 3(5), 745-754. http://dx.doi.org/10.4236/as.2012.35090

Dembitsky, V. M., Poovarodom, S., Leontowicz, H., Leontowicz, M., Vearasilp, S., Trakhtenberg, S., \& Gorinstein, S. (2011). The multiple nutrition properties of some exotic fruits: biological activity and active metabolites. Food Reserach International, 44(7), 1671-1701. http://dx.doi.org/10.1016/j.foodres.2011.03.003

Folch, J., Less, M., \& Stanley, G. H. S. (1957). A simple method for the isolation and purification of total lipides from animal tissues. Journal of Biological Chemistry, 226(1), 497-509. PMid:13428781.

Geőcze, K. C., Barbosa, L. C. A., Fidêncio, P. H., Silvério, F. O., Lima, C. F., Barbosa, M. C. A., \& Ismail, F. M. D. (2013). Essential oils from pequi fruits from the Brazilian Cerrado ecosystem. Food Research International, 54(1), 1-8. http://dx.doi.org/10.1016/j. foodres.2013.06.005

Hartman, L. \& Lago, R. C. A. (1973). Rapid preparation of fatty acids methyl esters. Laboratory Practice, 22(6), 475-476. PMid:4727126.

Higby, W. K. (1962). A simplified method for determination of some aspects of the carotenoid distribution in natural and carotene fortified orange juice. Journal of Food Science, 27(1), 42-49. http:// dx.doi.org/10.1111/j.1365-2621.1962.tb00055.x

Institute of Medicine. (2005). Dietary reference intakes for energy, carbohydrate, fiber, fat, fatty acids, cholesterol, protein, and amino acids. Washington: National Academy Press.

Lancaster, J. E., Lister, C. E., Ready, P. F., \& Triggs, C. M. (1997). Influence of pigment composition on skin color in a wide range of fruit and vegetables. Journal of the American Society for Horticultural Science, 122(4), 594-598.

Lima, A., Silva, A. M. O., Trindade, R. A., Torres, R. P., \& Mancini-Filho, J. (2007). Composição química e compostos bioativos presentes na polpa e na amêndoa de pequi (Caryocar brasiliense, Camb.)/ Chemical composition and bioactive compounds in the pulp and almond of pequi fruit. Revista Brasileira de Fruticultura, 29(3), 695698. http://dx.doi.org/10.1590/S0100-29452007000300052

McGuire, R. G. (1992). Reporting of objective color measurements. Hort Science, 27(12), 1254-1255.

Merril, A. L., \& Watt, B. K. (1973). Energy value of foods: basis and derivation. Washington: United States Departament of Agriculture.

Moura, N. F., Chaves, L. J., \& Naves, R. V. (2013). Caracterização física de frutos de pequizeiro (Caryocar brasiliense Camb.) do Cerrado. Revista Árvore, 37(5), 905-912. http://dx.doi.org/10.1590/S010067622013000500013

Morais, M. L., Silva, A. C. R., Araújo, C. R. R., Esteves, E. A., \& Dessimoni-Pinto, N. A. V. (2013). Determinação do potencial antioxidante in vitro de frutos do Cerrado brasileiro. Revista Brasileira de Fruticultura, 35(2), 355-360. http://dx.doi.org/10.1590/ S0100-29452013000200004

Novaes, P., Molinillo, J. M. G., Varela, R. M., \& Macías, F. A. (2013). Ecological phytochemistry of Cerrado (Brazilian savanna) plants. Phytochemistry Reviews, 12(4), 839-855. http://dx.doi.org/10.1007/ s11101-013-9315-3

Rodriguez-Amaya, D. B., Kimura, M., Godoy, H. T., \& Amaya-Farfan, J. (2008). Updated Brazilian database on food carotenoids: factors affecting carotenoid. Journal of Food Composition and Analysis, 21(6), 445-463. http://dx.doi.org/10.1016/j.jfca.2008.04.001 
Roesler, R., Malta, L. G., Carrasco, L. C., Holanda, R. B., Sousa, C. A. S., \& Pastore, G. M. (2007). Atividade antioxidante de frutas do Cerrado/Antioxidant activity of cerrado fruits. Ciência e Tecnologia de Alimentos, 27(1), 53-60. http://dx.doi.org/10.1590/S010120612007000100010

Swain, T., \& Hillis, W. E. (1959). The phenolic constituents of Prunus domestica L: the quantitative analysis of phenolic constituents. Journal of the Science of Food and Agriculture, 10(1), 63-81. http:// dx.doi.org/10.1002/jsfa.2740100110
Vera, R., Souza, E. R. B., Fernandes, E. P., Naves, R. V., Soares Júnior, M. S., Caliari, M., \& Ximenes, P. A. (2007). Caracterização física e química de frutos do pequizeiro (Caryocar brasiliense Camb.) oriundos de duas regiões no estado de Goiás, Brasil. Pesquisa Agropecuária Tropical, 37(2), 93-99.

Vera, R., Naves, R. V., Nascimento, J. L., Chaves, L. J., Leandro, W. M., \& Souza, E.R.B. (2005). Caracterização física de frutos do pequizeiro (Caryocar brasiliense Camb.) no estado de Goiás/Physical characterization of pequi fruits (Caryocar brasiliense Camb.) in Goiás state. Pesquisa Agropecuária Tropical, 35(2), 71-79. 